\title{
Botanical sources and sugar concentration of the nectar collected by two stingless bee species in a tropical African rain forest*
}

\author{
Robert KAJOBE ${ }^{\mathrm{a}, \mathrm{b}}$ \\ ${ }^{\text {a }}$ Faculty of Biology, Department of Behavioural Biology, Tropical Bee Research Unit, PO Box 80.086, 3508 TB \\ Utrecht, The Netherlands \\ ${ }^{\mathrm{b}}$ Permanent Address: Department of Forest Biology and Ecosystems Management, Faculty of Forestry and \\ Nature Conservation, Makerere University, PO Box 7062, Kampala, Uganda
}

Received 3 January 2005 - Revised 15 October 2005 - Accepted 10 August 2006

\begin{abstract}
Nectar foraging by species of two stingless bees was studied in an African tropical rain forest. Both species Hypotrigona gribodoi $(2-3 \mathrm{~mm})$ and Meliponula ferruginea $(6 \mathrm{~mm})$ collected nectar with a wide range of sugar concentration (H. gribodoi: 14.2-67.4\%; M. ferruginea: 9.1-63.4\%). H. gribodoi collected nectar of higher sugar concentration than M. ferruginea. Factors that influenced sugar concentration of collected nectar included botanic origin of the nectar, bee species, bee colonies, month of year, time of day and the local environment. Sugar concentration increased gradually from $0700 \mathrm{~h}$ to a peak at $1300 \mathrm{~h}$ and declined thereafter. H. gribodoi collected nectar from more diverse plant species than M. ferruginea. Sugar concentration for both bee species was higher during the dry season than the rainy season. Although the above factors may explain part of the variation in the sugar concentration of nectar, additional explanations lie in the behavioural differences among the bee species.
\end{abstract}

nectar concentration / nectar sources / Calliandra calothyrsus / foraging behaviour / Budongo Forest Reserve

\section{INTRODUCTION}

Several species of stingless bees can occur sympatrically and their diets partly overlap permitting access to the same resources by many colonies (Sommeijer et al., 1983; Roubik et al., 1986; Kleinert-Giovanini and Imperatriz-Fonseca, 1987; Ramalho et al., 1989; Ramalho, 1990; Roubik et al., 1995; Kajobe and Roubik, 2006). The overlap in diet can lead to competitive interactions (Hubbel and Johnson, 1977, 1978; Roubik and Aluja, 1983; Roubik, 1989). The competition for nectar can result in the evolution of not only morphological adaptations of both plants and animals but also in a wide range of nectar

Corresponding author: R. Kajobe,

kajobe@forest.mak.ac.ug

* Manuscript editor: B. Vassière and J. Pierre qualities and quantities presented by plants (Roubik, 1989; Biesmeijer et al., 1999b). Flower visitors can differentiate between the amount of nectar in flowers, its sugar concentration, and its composition in sugars, amino acids and lipids (Baker and Baker, 1975, 1983; Opler, 1983; Roubik and Buchmann, 1984; Roubik et al., 1995; Biesmeijer and Ermers, 1999).

Honey bees have a preference mainly for those plants that provide a better reward, that is the largest amount of pollen, or nectar, or both, those having more concentrated nectar, and those that have not been foraged on previously by other bees (Roubik, 1989). Factors that cause variation in harvested nectar sugar concentration include the botanical origin of nectar, local climate, as well as behavioural differences among bee species and among 


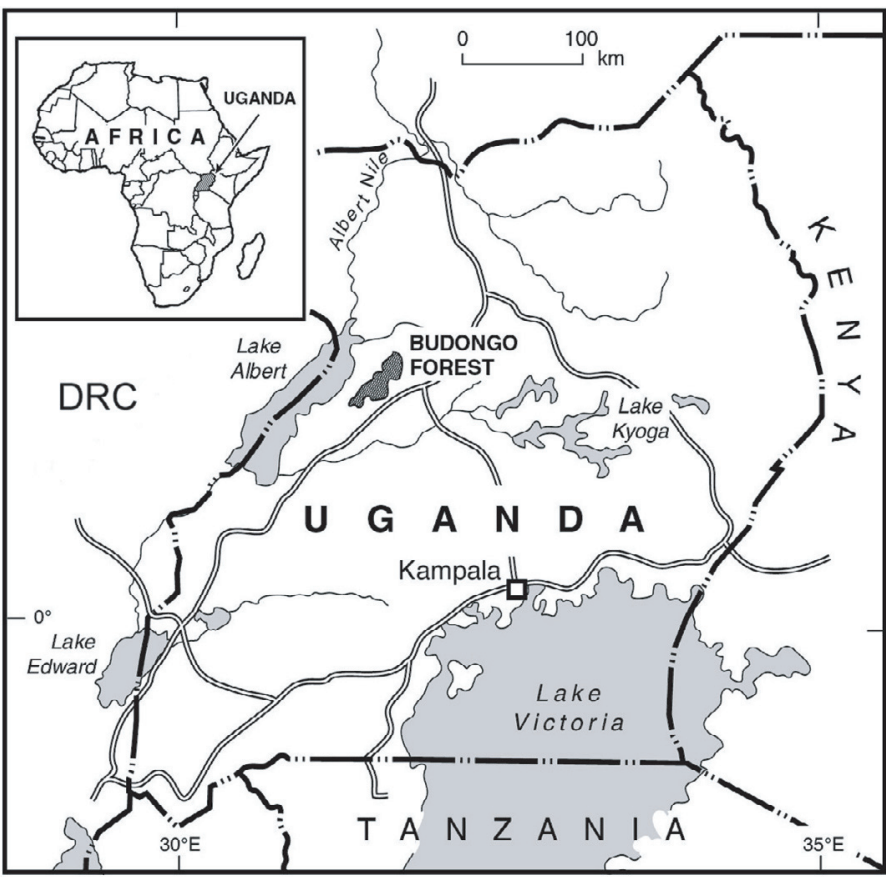

Figure 1. Location of the Budongo Forest Reserve $($ DRC $=$ Democratic Republic of Congo). colonies within the same species (Biesmeijer et al., 1999b). These authors concluded that the variation of climatological conditions between patches might lead to heterogeneous nectar rewards.

Spatial and temporal niche differentiation between sympatric stingless bee species can arise by differences in bee morphology, for example with body size, colour and mouth parts (Biesmeijer et al., 1999a). Resource partitioning can also be the result of behavioural differences among bee foragers, for example the timing of the foraging activity, the ability to recruit, the intrinsic collecting behaviour, aggressiveness, and the food selection (Frankie et al., 1976; Villanueva, 1994). Temporal resource partitioning was described by Frankie et al. (1976) who found that the species composition of bee fauna foraging on a particular flower patch changed over the course of a day, thus suggesting that differences in the timing of foraging may help to avoid direct competition among species at flowers. In that study, they noted a tendency for larger bees to forage earlier in the day compared to the smaller species.
Studies are very limited on the floral origin of nectar collected by African stingless bees. There has been no major study to fully explain the nectar foraging ecology of social bees in African tropical rain forests. The patterns and ecological impact of floral choice and foraging behaviour of social bees in this environment are largely unknown. This study was therefore aimed at answering the following questions: what are the important nectar sources of stingless bees in the Budongo forest reserve? What is their diversity? What factors influence the sugar concentration of collected nectar, in particular is there an effect of the bee species on the concentration of the nectar collected? A comparison between honey bees and stingless bees was made in an effort to understand the ecology of their nectar foraging behaviour.

\section{MATERIALS AND METHODS}

\subsection{Study site}

The main study was conducted in the Budongo Forest Reserve (BFR), which is a tropical rain forest located in mid-western Uganda. It is an outlier of 
the great Ituri forest of the Democratic Republic of Congo (Fig. 1). It covers an area of $825 \mathrm{~km}^{2}$, making it Uganda's biggest forest reserve (Hamilton, 1984); $53 \%$ of it is continuous forest cover while the remaining comprises grassland communities. It is located east of the Western rift valley escarpment and Lake Albert between $1^{\circ} 35^{\prime}$ and $1^{\circ} 55^{\prime}$ $\mathrm{N}$, and $31^{\circ} 18^{\prime}$ and $31^{\circ} 42^{\prime} \mathrm{E}$ (Howard, 1991). The forest lies at an average altitude of $1100 \mathrm{~m}$ (minimum $750 \mathrm{~m}$ and maximum $1250 \mathrm{~m}$ ) above sea level (Eggeling, 1947).

\subsection{Bee colonies}

We used four natural nests of two stingless bee species, two colonies of Hypotrigona gribodoi and two of Meliponula ferruginea. These two species were selected because they represent the two genera of stingless bees that have been identified in Uganda. The colonies were located at most $80 \mathrm{~m}$ apart in various tree cavities close to the border of the forest. The stingless bees were identified based on Eardley (2004) and their identity was confirmed by David W. Roubik at Smithsonian Tropical Research Institute. Measurement of the bee sizes (dry body length) was recorded in the Royal Museum for Central Africa, Tervuren, Belgium, using an ocular micrometer on a stereoscopic microscope. The smaller bee species, $H$. gribodoi $(2-3 \mathrm{~mm})$ is pale in colour. Two morphs of $M$. ferruginea $(6 \mathrm{~mm})$, one black and the other brown have been identified in Uganda. They were previously called Meliponula erythra, but are now regarded as species synonyms (Eardley, 2004). The brown form is the one that exists in Budongo forest reserve and was therefore used in this study.

\subsection{Sampling and analysis of nectar collected by $H$. gribodoi and M. ferruginea}

From March to August 2002, nectar samples were taken once a week from 10 returning foragers per colony, five times a day at 0600-0700 h, 0900$1000 \mathrm{~h}, 1100-1200 \mathrm{~h}, 1300-1400 \mathrm{~h}$ and 1500$1600 \mathrm{~h}$ local time. The methods used were similar to those used by Biesmeijer et al. (1999b). At the nest entrances, returning nectar foragers were caught with a net. Nectar foragers carried pollen of different colours and on different parts of their bodies (but did not carry pollen loads in their corbiculae).
Nectar was collected from foragers by forcing the bees to expel their crop load into a $20 \mu \mathrm{L}$ capillary tube for the small bee, $H$. gribodoi and $50 \mu \mathrm{L}$ for M. ferruginea. In the case of $H$. gribodoi, samples from $2-3$ bees were occasionally combined to obtain more reliable sugar concentration values. Concentration of sugar (actually total dissolved solids) in the nectar was measured with a hand refractometer corrected for ambient temperature (results expressed in $\mathrm{g}$ per $100 \mathrm{~g}$ of solution). Bees carrying loads with less than 5\% in sugar concentration were ignored because they probably consisted mainly of water foragers (Roubik and Buchmann, 1984). Data on ambient temperature was taken at each time of nectar collection.

\subsection{Identification of nectar and pollen sources}

Nectar foragers carried pollen of different colours on different parts of their bodies. These pollen grains adhering to the body of the bees were sampled by trapping the bee with glycerine jelly and we analysed this pollen to identify the nectar sources used by the bees. We obtained a wide variety of samples by selectively sampling foragers from each visually distinguishable pollen colour type. Such a sampling method can cause a slight overestimation of the diversity in nectar diet (Biesmeijer et al., 1999b). Several representatives of each colour of pollen were acetolysed and mounted in glycerine jelly for microscopic examination (Sawyer, 1981). The colour and amount of the pollen was recorded. Most slides contained only one type of pollen and slides that contained more than one type were not included in our analysis. The different pollen types were identified by making use of our reference collection and by consulting Hamilton (1972). A nectar source was referred to as a major source if it contributed at least $30 \%$ of the samples from one colony during a day of observation. All other sources were referred to as minor sources.

\subsection{Nectar collection from Calliandra calothyrsus by stingless bees and Apis mellifera}

This second study was undertaken to provide background data on the possible changes in the concentration of the crop content of the stingless bees 
Table I. Nectar concentration collected by foragers from four colonies of two stingless bee species upon their return to the nest.

\begin{tabular}{lccccc}
\hline Colony number & Number of samples analyzed & Minimum & Maximum & Mean & Standard deviation \\
\cline { 3 - 6 } & \multicolumn{5}{c}{ Nectar concentration (g solute / 100 g solution) } \\
\hline \multirow{3}{*}{260} & Melipona ferruginea & & & \\
2 & 260 & 9.1 & 63.4 & 42.2 & 1.72 \\
& & 12.5 & 63.2 & 39.8 & 1.62 \\
1 & 313 & Hypotrigona gribodoi & & \\
2 & 313 & 14.2 & 67.4 & 43.7 & 1.56 \\
\hline
\end{tabular}

between the flowers they foraged upon and their return to the nest. Also we included honey bees in this study to extend our sampling to three species of social bees. Data were taken once a week from June to September 2002 on flower visitation and concentration of collected nectar from $C$. calothyrsus (Mimosaceae) by A. mellifera, H. gribodoi and M. ferruginea in Nyabyeya Forestry College agroforestry demonstration farm. The farm was planted with about 5 ha of $C$. calothyrsus, a shrub that reached a height of 4-6 $\mathrm{m}$ and flowers throughout the year and is a primary source of nectar for bees. Most flowers open at $1600 \mathrm{~h}$ for a single night. Foragers were captured immediately after imbibing nectar for an uninterrupted period. Nectar samples were taken once a week from 2-5 foragers of each bee species five times a day at $0600-0700 \mathrm{~h}, 0700-0800 \mathrm{~h}, 1600$ $1700 \mathrm{~h}, 1700-1800 \mathrm{~h}$ and $1800-1900 \mathrm{~h}$. These times were selected in relation to the observed period of anthesis of C. calothyrsus in the agro-forestry farm. The same methods, as previously described in 2.3 and 2.4, were used to extract the crop content from the bees and identify the nectar sources respectively. There was little chance the nectar thus sampled came from other flower species or colony stores, since floral constancy of stingless bees is quite high (Slaa et al., 1998). The time taken to visit one flower and five flowers in succession was recorded for some selected individual bees to determine the handling time and foraging speed for the three bee species gathering nectar on $C$. calothyrsus.

\subsection{Data analysis}

The main dependent variable in this study was the sugar concentration of the crop content expressed as gram (g) of solute per $100 \mathrm{~g}$ of solution. These percentages ranged from 9.1 and $67.4 \%$, and so the data was analyzed as proportion after an Arcsine Square root Transformation (Sokal and Rohlf, 1995). To report the means, the results were converted back to percentages. A nested ANOVA was performed to determine the factors influencing sugar concentration of collected nectar. The model used was:

Nectar concentration $=$ Bee species + Colony (bee species) + Month + Time of day + Month $\times$ Time of day + Bee species $\times$ Month + Bee species $\times$ Time of day + Bee species $\times$ Month $\times$ Time of day Colony (bee species) $\times$ Month + Colony (bee species) $\times$ Time of day + Colony (bee species) $\times$ Month $\times$ Time of day + error. Bee species, month and time of day were treated as fixed factors while colony was considered random. Pearson correlation coefficients were calculated to determine the relationship between the temperature and the concentration of collected nectar. The average diversity of pollen types per nest was calculated using a Shannon-Weaver index of diversity: $\mathrm{H}^{\prime}{ }_{\mathrm{ik}}=-\Sigma_{\mathrm{j}}$ $\left[\left\{\mathrm{N}_{\mathrm{ijk}} / \Sigma_{\mathrm{j}}\left(\mathrm{N}_{\mathrm{ijk}}\right)\right\} \ln \left\{\mathrm{N}_{\mathrm{ijk}} / \Sigma_{\mathrm{j}}\left(\mathrm{N}_{\mathrm{ijk}}\right)\right\}\right]$ in which $\mathrm{H}^{\prime}{ }_{\mathrm{ik}}$ is Shannon-Weaver's index of colony i, over one month $\mathrm{k}$ and $\mathrm{N}$ is the number of pollen types. Indices were calculated for each colony per month and thereafter averaged. Kruskal-Wallis tests were carried out to compare the nectar handling time and foraging speed on Calliandra calothyrsus.

\section{RESULTS}

\subsection{Sugar concentration of collected nectar}

The two stingless bee species $H$. gribodoi and $M$. ferruginea collected nectar with a wide range of sugar concentrations (H. gribodoi: 14.2-67.4\%; M. ferruginea: 9.163.4\%; Tab. I). Overall, H. gribodoi collected 


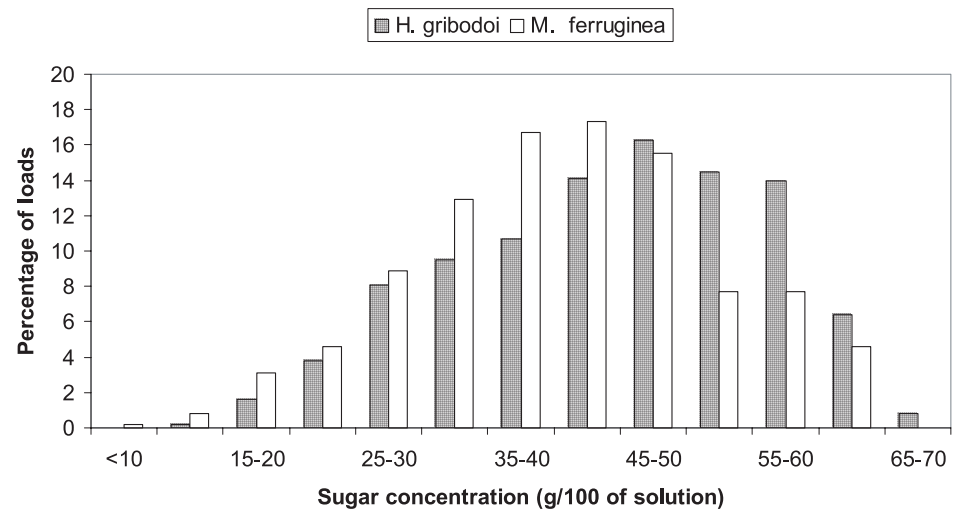

Figure 2. Compared sugar concentration of nectar collected by the foragers of two species of stingless bees over 6 months in the Budongo Forest (March-August 2002).

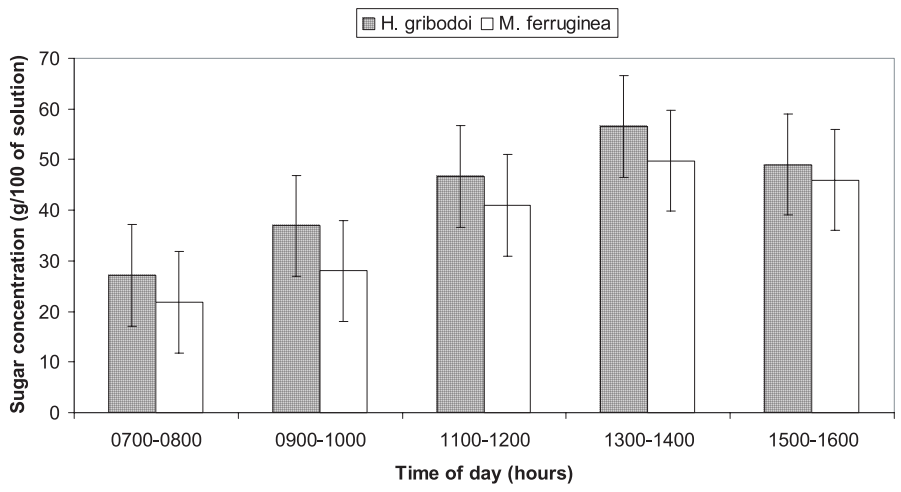

Figure 3. Effect of the time of day (local time) on the sugar concentration of nectar collected by the foragers of two species of stingless bees polled together over 6 months in the Budongo Forest (March-August 2002).

nectar with significantly higher sugar concentration compared to M. ferruginea (Fig. 2) across each of the daily sampling periods (Fig. 3). Sugar concentration increased gradually from $0700 \mathrm{~h}$ in the morning to a peak at $1300 \mathrm{~h}$ in the afternoon and there after it declined.

\subsection{Main factors influencing sugar concentration of collected nectar}

The species of bee, colony within species, month of year and the time of day when the nectar was collected all had a significant effect on the sugar concentration of collected nectar (Tab. II). There was significant difference in monthly sugar concentration for the two bee species (Tab. II). The mean nectar concentration was higher during the dry season (June: $48.9 \pm 10.8$ and July: $47.8 \pm 11.0$ ) compared to the rainy season (March: $40.2 \pm 10.0$ and April: $32.5 \pm 9.9$ ). There was a positive correlation between the concentration of collected nectar and temperature (M. ferruginea: 2-tailed, $\mathrm{r}=0.846, \mathrm{~N}=260$, and $H$. gribodoi: 2 tailed, $\mathrm{r}=0.559, \mathrm{~N}=313, P<0.0001$ for both species).

\subsection{Nectar and pollen sources}

By means of palynological analysis, 33 out of the 52 nectar sources could be identified to species level. Overall, more plants were major nectar sources for $H$. gribodoi than for 
Table II. Nested ANOVA with the effect of bee species, colonies nested within species, month of year and time of day on the sugar concentration of collected nectar. The blank spaces correspond to non-significant results.

\begin{tabular}{lccccc}
\hline Source of variation & df & SS & MS & $F_{\text {cal }}$ & $P$ values \\
\hline Bee species & 1 & 0.1056 & 0.1056 & 88.00 & $* *$ \\
Colonies (species) & 2 & 0.0223 & 0.0111 & 9.25 & $*$ \\
Month & 5 & 4.1933 & 0.2097 & 174.00 & $* *$ \\
Time of day & 4 & 12.6540 & 0.1318 & 109.83 & $* *$ \\
Month $\times$ Time of day & 20 & & & & \\
Bee species $\times$ Month & 5 & & & & \\
Bee species $\times$ Time of day & 4 & & & & \\
Bee species $\times$ Month $\times$ Time of day & 20 & & & & \\
Colony(species) $\times$ Month & 10 & & & & \\
Colony (species) $\times$ Time of day & 8 & & & & \\
Colony (species) $\times$ Month $\times$ Time of day & 40 & & & \\
Error & 1026 & 1.2343 & 0.0012 & & \\
Total & 1145 & 18.2095 & & &
\end{tabular}

Table III. Important nectar sources for two species of stingless bees in the Budongo forest over six months of observation (March-August 2002). Shading indicates the periods of foraging on the given source.

\begin{tabular}{|c|c|c|c|c|c|c|}
\hline Plant species & Family & March & May & June & July & August \\
\hline \multicolumn{7}{|c|}{ Meliponula ferruginea } \\
\hline Acacia sp. & Fabaceae & & & & & \\
\hline Albizia sp. & Fabaceae & & & & & \\
\hline Calliandra calothyrsus & Fabaceae & & & & & \\
\hline Coffea sp. & Rubiaceae & & & & & \\
\hline Eucalyptus sp. & Myrtaceae & & & & & \\
\hline Musa sp. & Musaceae & & & & & \\
\hline \multicolumn{7}{|c|}{ Hypotrigona gribodoi } \\
\hline Acacia sp. & Fabaceae & & & & & \\
\hline Albizia sp. & Fabaceae & & & & & \\
\hline Bidens sp. & Asteraceae & & & & & \\
\hline Calliandra calothyrsus & Fabaceae & & & & & \\
\hline Combretum sp. & Combretaceae & & & & & \\
\hline Eucalyptus sp. & Myrtaceae & & & & & \\
\hline Musa sp. & Musaceae & & & & & \\
\hline Type 7 & Unidentified & & & & & \\
\hline Type 14 & Asteraceae & & & & & \\
\hline Type 23 & Unidentified & & & & & \\
\hline Syzigium sp. & Myrtaceae & & & & & \\
\hline Vernonia sp. & Asteraceae & & & & & \\
\hline
\end{tabular}

M. ferruginea. The two most important families were Fabaceae and Asteraceae. Three of the major species of Fabaceae (Acacia sp., Albizia sp. and Calliandra calothyrsus) were collected by both $H$. gribodoi and M. ferruginea (Tab. III). The three species of Asteraceae (Bidens sp., Vernonia sp. and type 14) were exclusively collected by $H$. gribodoi. Eucalyp- tus sp. being one of the two major species of Myrtaceae was collected by both stingless bee species. Combretaceae, Musaceae and Rubiaceae accounted for one major source each. The families of two major types (Type 7 and Type 23) could not be determined. Calliandra calothyrsus was used throughout the observation period by both stingless bee species. 
Table IV. Number of nectar sources and ShannonWeaver's index of diversity for Hypotrigona gribodoi and Melipona ferruginea given as average over the 6 months of sampling.

\begin{tabular}{lcc}
\hline Colony & $\begin{array}{c}\text { Total number of plant Diversity index }\left(\mathrm{H}^{\prime}\right) \\
\text { species foraged upon }\end{array}$ \\
\hline \multicolumn{3}{c}{ Meliponula ferruginea } \\
1 & 18 & 1.78 \\
2 & 13 & 1.67 \\
\multicolumn{3}{c}{ Hypotrigona gribodoi } \\
1 & 24 & 2.19 \\
2 & 29 & 2.23 \\
\hline
\end{tabular}

During the study period, the two stingless bee species collected nectar from 52 different plant species, 13 of which were shared. M. ferruginea used 27 plant species (14 exclusively) and H. gribodoi used 38 plant species (25 exclusively). $H$. gribodoi collected nectar from a wider range of plants species than $M$. ferruginea. The average Shannon-Weiner index of diversity ( $\left.\mathrm{H}^{\prime}\right)$ was higher for $H$. gribodoi than for M. ferruginea (Tab. IV).

\subsection{Effects of nectar source taxa on sugar concentration}

The two stingless bee species shared 13 nectar sources out of which $H$. gribodoi collected 8 of higher sugar concentration than M. ferruginea (Tab. V). H. gribodoi collected a significantly lower sugar concentration from the plant species it shared with $M$. ferruginea than from sources that it used exclusively $(\mathrm{t}=$ 2.69; $P=0.015$; shared sources: mean $=43$; $\mathrm{N}=13$; exclusive sources: mean $=51 ; \mathrm{N}=6$; Tab. V). Two of the nectar sources exclusively used by M. ferruginea had the lowest concentrations (Type 11 with $24.5 \%$ and Type 20 with $29.2 \%)$

\subsection{Nectar collection from Calliandra calothyrsus by stingless bees and Apis mellifera}

C. calothyrsus was a major source of nectar for the three bee species and was visited by a large variety of other insects. Observations of flower visitation on $C$. calothyrsus showed that A. mellifera was the most common visitor while M. ferruginea was also quite common and $H$. gribodoi was quite rare. Among the bee species, A. mellifera crop content had the lowest mean sugar concentration $(40.3 \pm$ 7.9) while $H$. gribodoi had the highest (44.9 \pm 9.4; Tab. VI). The concentration of nectar in the crop of foragers of $\mathrm{H}$. gribodoi and $M$. ferruginea captured at the nest entrances was similar to that of the crop content from bees captured at flowers immediately after imbibing the nectar for an uninterrupted period (H. gribodoi: ANOVA: $\mathrm{F}=0.92 ; \mathrm{df}=1 ; \mathrm{N}=$ $85 ; P>0.05 ; M$. ferruginea: ANOVA: $\mathrm{F}=$ $0.98 ; \mathrm{df}=1 ; \mathrm{N}=85 ; P>0.05)$. The species of bee had a significant effect on the time taken to visit one flower (handling time) and the foraging speed. It was lowest for $A$. mellifera and highest for $H$. gribodoi (One flower: KruskalWallis test: $\mathrm{df}=2, \mathrm{~N}=85, P \leq 0.0001$; Five flowers: Kruskal-Wallis test: $\mathrm{df}=2, \mathrm{~N}=85$, $P<0.0001$; Tab. VI).

\section{DISCUSSION}

\subsection{Influence of bee size on sugar concentration of collected nectar}

Distinctive preferences for nectar of differing sugar concentrations were found for the species. The smaller bee species $H$. gribodoi $(2-3 \mathrm{~mm})$ preferred sugar of significantly higher concentration than $M$. ferrug inea $(6 \mathrm{~mm})$. If similar volumes are compared, a relatively highly concentrated nectar source is energetically more profitable than or comparable to a nectar source of lower concentration (Roubik, 1989). Since we used $20 \mu \mathrm{L}$ capillary tubes to collect crop loads of $\mathrm{H}$. gribodoi and $50 \mu \mathrm{L}$ for $M$. ferruginea, it is hypothised that the crop load of the smaller bee, $H$. gribodoi was also smaller. Probably if all factors were kept constant (e.g. weather conditions, distance to food source), the energy saved by taking less concentrated nectar would not compensate foragers of $H$. gribodoi for the calorific loss. By harvesting significantly more concentrated nectar, it is possible that 
Table V. Sugar concentration $(\mathrm{g} / 100 \mathrm{~g})$ of nectar of different botanic origin obtained from the crop of returning foragers of two stingless bee species in the Budongo forest (data collected between March and August 2002).

\begin{tabular}{|c|c|c|c|c|c|c|}
\hline \multirow[t]{2}{*}{ Plant species } & \multicolumn{2}{|c|}{ Hypotrigona gribodoi } & \multicolumn{2}{|c|}{ Melipona ferruginea } & \multirow[t]{2}{*}{$t$-value } & \multirow[t]{2}{*}{$P$ value } \\
\hline & Mean & $\mathrm{N}$ & Mean & $\mathrm{N}$ & & \\
\hline Calliandra calothyrsus & 45.4 & 147 & 41.2 & 127 & 2.24 & 0.026 \\
\hline Eucalyptus sp. & 48.1 & 129 & 44.3 & 98 & 3.04 & 0.003 \\
\hline Albizia sp. & 44.3 & 82 & 40.2 & 102 & 2.24 & 0.026 \\
\hline Acacia sp. & 49.1 & 76 & 43.2 & 97 & 2.44 & 0.016 \\
\hline Musa sp. & 40.4 & 56 & 41.3 & 64 & -1.67 & 0.098 \\
\hline Bidens sp. & 46.2 & 45 & 38.4 & 39 & 3.40 & 0.001 \\
\hline Type 14 (Asteraceae) & 42.1 & 41 & 39.4 & 9 & 2.45 & 0.018 \\
\hline Vernonia sp. & 52.1 & 39 & 49.2 & 53 & 3.27 & 0.002 \\
\hline Syzigium sp. & 39.6 & 28 & 42.3 & 25 & 2.11 & 0.040 \\
\hline Type 7 (Unidentified) & 43.2 & 22 & 46.5 & 42 & 2.75 & 0.008 \\
\hline Type 23 (Unidentified) & 38.2 & 19 & 37.1 & 8 & 1.76 & 0.091 \\
\hline Combretum sp. & 37.8 & 17 & 32.3 & 11 & 3.61 & 0.001 \\
\hline Coffea sp. & 40.3 & 15 & 41.2 & 6 & 1.44 & 0.166 \\
\hline Markhamia lutea & 56.5 & 13 & & & & \\
\hline Mangifera indica & 48.4 & 12 & & & & \\
\hline Iротеа sp. & 54.4 & 9 & & & & \\
\hline Senna sp. & 47.1 & 6 & & & & \\
\hline Carica papaya & 58.2 & 5 & & & & \\
\hline Citrus sp. & 45.3 & 3 & & & & \\
\hline Type11 (Unidentified) & & & 24.5 & 5 & & \\
\hline Type 20 (Unidentified) & & & 29.2 & 4 & & \\
\hline
\end{tabular}

Table VI. Sugar concentration of the crop content,handling time and foraging speed for three species of bees gathering nectar on Calliandra calothyrsus $(\mathrm{N}=85$ for all cases; mean $\pm \mathrm{SD})$.

\begin{tabular}{lcccc}
\hline $\begin{array}{l}\text { Bee species and body length } \\
\text { (measured on dry specimens) }\end{array}$ & $\begin{array}{c}\text { Returning foragers } \\
\text { caught at nest entrance }\end{array}$ & $\begin{array}{c}\text { Foragers caught at } \\
\text { departure from flowers }\end{array}$ & $\begin{array}{c}\text { Time to visit } \\
\text { 1 flower }\end{array}$ & $\begin{array}{c}\text { Time to visit } \\
\text { 5 flowers }\end{array}$ \\
\hline & $\%$ TDS & $\%$ TDS & $\mathrm{s}$ & $\mathrm{S}$ \\
A. mellifera $(11 \mathrm{~mm})$ & & $40.3 \pm 7.9$ & $4.3 \pm 1.6$ & $26.4 \pm 5.1$ \\
M. ferruginea $(6 \mathrm{~mm})$ & $41.9 \pm 12.4$ & $42.6 \pm 6.8$ & $5.2 \pm 1.7$ & $28.2 \pm 4.5$ \\
H. gribodoi $(2-3 \mathrm{~mm})$ & $44.1 \pm 11.8$ & $44.9 \pm 9.4$ & $5.5 \pm 2.0$ & $31.3 \pm 4.0$ \\
\hline
\end{tabular}

foragers of $H$. gribodoi are able to reduce the energy needed to evaporate the collected nectar to the normal concentration of stingless bee honey which is about 70\% (Vit et al., 2004). Roubik and Buchmann (1984) noted that even if greatly rewarding resources are present, less rewarding ones might be preferred if the overall amount of that resource in the patch is high and/or easy to forage. However, a sample size of two stingless bee species with two colonies of each is far too small to enable the drawing of general conclusions as to the importance of the size factor on the nectar selection process of stingless bees.
The two bee species collected nectar with a wide range of sugar concentrations suggesting that the concentrations used partly overlapped between the species. The wide range of sugar concentration can be favourable to both bee species because it can ultimately result in survival of these species in cases of adverse environmental conditions and inadequate nectar resources. Accessibility to nectar sources by the bee species may have limited influence on the concentration of collected nectar because the bee species collected nectar from plant species in the same families and shared some of their major nectar sources. 


\subsection{Effects of nectar and pollen source on sugar concentration of nectar}

Bees must possess a mechanism that can discriminate between nectars of different sweetness to be able to collect the optimal sugar concentration. Other possible mechanisms are distinction by taste or sensitivity to sugar concentration (Biesmeijer et al., 1999b). Variation in plant species used by bee species is one of the factors that explain the variation in sugar concentration of bee collected nectar. The two bee species shared 13 sources, some of which were among their major sources. Of the total range of nectar and pollen sources used by the two species, $H$. gribodoi tended to use plants with higher average nectar concentration. Moreover, the shared nectar sources were those that provided significantly less rich nectar. Thus the botanical origin of the nectar seems to explain only part of the differences in the sugar harvest of the two species.

\subsection{Temporal influence on sugar concentration of collected nectar}

Another factor that may explain some of the variation in sugar concentration of collected nectar is time of day. This study revealed that the sugar concentration of the bee collected nectar increased from early morning till 1300$1400 \mathrm{~h}$ and declined thereafter. This finding is in line with the prediction that higher solar radiation causes evaporation and results in more concentrated nectar in the flowers (Roubik and Buchmann, 1984; Roubik; 1989). Sugar concentration of collected nectar varied during the months (seasons) of data collection. Monthly changes in flowering phenology are likely to produce differences in nectar richness. With more rain and fewer sunny periods, there will be a low concentration of bee collected nectar. During the dry season, the wind evaporates some of the water in the nectar thereby making it more concentrated.

\subsection{Behavioural factors regulating partitioning of nectar resources}

The diet diversity of $H$. gribodoi was higher than that of $M$. ferruginea. The recruitment strategies of the bees to food sources may probably explain the differences in diversity. In a related study (Kajobe and Echazarreta, 2005) found that workers of M. ferruginea exited their nests in characteristically distinct foraging bouts suggesting that the recruitment methods employed may be direct leading or "piloting" (Esch et al., 1965; Esch, 1967; Johnson, 1987). Such recruitment trait could have led to the reduced diversity in nectar sources for $M$. ferruginea. This hypothesis needs to be tested further because there is little doubt that it is adaptive for a bee to occasionally sample flowers other than those on which it is specialising. Such behaviour may frequently occur in tropical habitats where hundreds of flower species can be presented at one time (Roubik and Buchmann, 1984).

\subsection{Nectar collection from Calliandra calothyrsus by stingless bees and Apis mellifera}

Despite the fact that bees might have harvested nectar from different flowers, there was no significant difference between the concentration of nectar harvested by foragers of $H$. gribodoi and M. ferruginea captured at the hive entrances as compared to nectar from bees captured at flowers. This is in agreement with Roubik et al. (1995) who concluded that nectar recently stored in the crop of bees is not dehydrated. A. mellifera was the most common forager on $C$. calothyrsus. Such a situation could have arisen as a result of contest competition (Milinski and Parker, 1991) during which the stingless bees are displaced from the resource as a result of aggressive behaviour of A. mellifera. Although the competing stingless bees generally shared the resource, $M$. ferruginea, was competitively stronger than $H$. gribodoi and exploited the shared resource faster.

Various sizes and shapes of bee mouthparts may results in differences in rate at which they harvest nectar of differing concentration and from different floral types. Such morphological differences may ultimately lead to nectar resource partitioning. Apart from the differences that floral structure enforces in regulating visitor type, resource partitioning 
should reflect parameters of foraging success that are dependent upon the physical properties of nectar and upon the bees themselves (Roubik and Buchmann, 1984). Comparison of the nectar intake rate of the three bee species shows that the larger bees tended to harvest nectar faster. Fast foragers, which suggest higher nectar intake rate, collected more dilute nectar. By imbibing more dilute nectar at a faster rate, foragers of A. mellifera may have reached a balance between foraging energetics and profit.

Based on these results, it is concluded that the botanic origin of the nectar, preference for certain sugar concentration, local environmental conditions, temporal influences and colony recruitment behaviour may be used to explain part of the variation in sugar concentration of the nectar collected. Other factors (not tested in this study) that may influence sugar concentration of the nectar collected include distance of flowers from a bee nest, the number and arrangement of available flowers, floral morphology, and the willingness of nest mates to accept nectar from a returning forager (Roubik and Buchmann, 1984; Roubik et al., 1995).

\section{ACKNOWLEDGEMENTS}

I am grateful to the British Ecological Society (BES) and the Faculty of Forestry and Nature Conservation, Makerere University for funding this research. I especially thank Dr. J.R.S. Kaboggoza and Professor J. Obua for their support. I am grateful to Dr. David W. Roubik who confirmed the identity of the stingless bee species. I also thank the Royal Museum for Central Africa, Tervuren, in Belgium who sponsored me to study their bee collection in June 2003.

Origine botanique et concentration en sucres du nectar récolté par deux abeilles sans aiguillon dans une forêt pluviale tropicale africaine.

concentration en sucres / nectar / plante nectarifère / comportement de butinage / abeille sans aiguillon / Apidae / Calliandra calothyrsus / Ouganda

Zusammenfassung - Botanische Herkunft und Zuckerkonzentration des Nektars, gesammelt in einem afrikanischen Regenwald von zwei Arten der Stachellosen Bienen. Das Nektarsammeln zweier Arten von Stachellosen Bienen wurde von März bis August im Budonge Waldreservat im mittelwestlichen Uganda untersucht. Hauptsächliches Ziel war, die Einflussfaktoren der Zuckerkonzentration des gesammelten Nektars zu bestimmen. Es wurden jeweils zwei natürliche Nester von $\mathrm{Hy}$ potrigona gribodoi und Meliponula ferruginea genutzt. Einmal pro Woche wurden zu 5 verschiedenen Tageszeiten Nektarproben von 10 zurückkehrenden Sammlerinnen genommen. Ein weiteres Experiment zur Bestimmung möglicher Änderungen der Konzentration des Honigmageninhalts zwischen den besammelten Blüten und der Rückkehr zum Nest wurden an der Stachellosen Biene Calliandra calothyrsus unternommen. In dieses Experiment wurden auch Honigbienen eingeschlossen. Einmal pro Woche wurden 5 mal pro Tag Nektarproben von 2-5 Sammlerinnen jeder Bienenart genommen.

Der von den beiden Stachellosen Bienen gesammelte Nektar umfasste eine weite Spanne unterschiedlicher Zuckerkonzentrationen (H. gribodoi: 14,267,4 \%; M. ferruginea: 9,1-63,4 \%; Tab. I). H. gribodoi sammelte zu jeder der untersuchten Tageszeiten Nektar mit signifikant höherer Zuckerkonzentration als M. ferruginea (Abb. 2, 3). Die Zuckerkonzentration nahm vom Morgen bis zum Spitzenwert am Nachmittag zu und nahm dann wieder ab. Die Bienenart, die Kolonie innerhalb der Spezies, der Jahresmonat und die Tageszeit, zu der Nektar gesammelt wurde, hatten alle einen signifikanten Effekt auf dessen Zuckerkonzentration (Tab. II).

Von den 52 besammelten Nektarquellen wurden 33 bis zur Art bestimmt. H. gribodoi nutzte 38 Pflanzenarten, $M$. ferruginea 27 . Beide Bienenarten hatten 13 Nektarquellen gemeinsam (Tab. V). C. calothyrsus war für drei Bienenarten die Hauptquelle (Apis mellifera, H. gribodoi und M. ferruginea), hierbei war A. mellifera der häufigste Besucher. Der Honigblaseninhalt von A. mellifera wies die niedrigste mittlere Zuckerkonzentration auf (40,3 \pm $7,9)$, bei $H$. gribodoi war sie am höchsten $(44,9 \pm$ 9,4; Tab. VI). Die Nektarkonzentration in der Honigblase von am Nesteingang gefangenen $\mathrm{H}$. gribodoi und $M$. ferruginea war ähnlich zu der von an Blüten abgefangenen Bienen.

Der weite Bereich von Zuckerkonzentrationen kann ultimativ zu einer Auslese dieser Arten bei schlechten Umgebungsbedingungen oder ungeeigneten Nektarquellen führen. Es wurden klare Bevorzugungen für Nektare unterschiedlicher Zuckerkonzentrationen gefunden. Möglicherweise können Sammlerinnen von $H$. gribodoi durch das Sammeln von höher konzentriertem Nektar die zur Verdunstung des gesammelten Nektars bis zu der für Stachellose Bienen normalen Konzentration von $70 \%$ benötigte Energie reduzieren. Das Ansteigen der Zuckerkonzentration des von den Bienen gesammelten Nektars vom Morgen bis zum Nachmittag stimmt mit der Vorhersage überein, dass die durch die höhere Sonneneinstrahlung verursachte 
Verdunstung zu einer höheren Nektarkonzentration in den Blüten führt. Die botanische Herkunft des Nektars, die Bevorzugung bestimmter Zuckerkonzentrationen, die örtliche Umgebung und zeitliche Einflüsse auf das Rekrutierungsverhalten der Völker können einen Teil der Variation in den Zuckerkonzentrationen des gesammelten Nektars erklären.

\section{Nektarkonzentration / Nektarquellen / Callian- dra calothyrsus / Sammelverhalten / Budongo Waldreservat / Uganda}

\section{REFERENCES}

Baker H.G., Baker I. (1975) Studies of nectar constitution and pollinator-plant coevolution, in: Gilbert L.E., Raven P.H. (Eds.), Animal and plant coevolution, Austin, Texas, USA, pp. 100-138.

Baker H.G., Baker I. (1983) Floral nectar sugar constituents in relation to pollinator type, in: Jones C.E., Little R.J. (Eds.), Handbook of experimental pollination biology, Van Nostrand Reinhold, New York, pp. 117-141.

Biesmeijer J.C., Ermers M.C.W. (1999) Social foraging in stingless bees: how colonies of Melipona fasciata choose among nectar sources, Behav. Ecol. Sociobiol. 46, 129-140.

Biesmeijer J.C., Richter J.A.P., Smeets M.A.J.P., Sommeijer M.J. (1999a) Niche differentiation in nectar collecting stingless bees: the influence of morphology, floral choice and interference competition, Ecol. Entomol. 24, 1-9.

Biesmeijer J.C., Smeets M.J.A.P., Richter J.A.P., Sommeijer M.J. (1999b) Nectar foraging by stingless bees in Costa Rica: botanical and climatological influences on sugar concentration of nectar collected by Melipona, Apidologie 30, 43-55.

Eardley C.D. (2004) Taxonomic revision of the African stingless bees (Apoidea: Apidae: Apinae: Meliponini), Afr. Plant Prot. 10, 63-96.

Eggeling W.J. (1947) Observations on the ecology of Budongo rain forest, Uganda, J. Ecol. 44, 20-87.

Esch H., Esch I., Kerr W.E. (1965) Sound: an element common to communication of stingless bees and to dances of the honey bee, Science 149, 320-321.

Esch H. (1967) The evolution of bee language, Sci. Am. 216, 97-104.

Frankie G.W., Opler P.A., Bawa K.S. (1976) Foraging behaviour of solitary bees: Implications for outcrossing of a neotropical forest tree species, J. Ecol. 64, 1049-1057.

Hamilton A.C. (1972) The interpretation of pollen diagrams from highland Uganda, Paleoecol. Africa 7, 46-149.

Hamilton A. (1984) Deforestation in Uganda, Oxford University Press, Nairobi.
Howard P.C. (1991) Nature conservation in Uganda's tropical forest reserves. IUCN, Gland, Switzerland.

Hubbell S.P., Johnson L.K. (1977) Competition and nest spacing in a tropical stingless bee community, Ecology 58, 949-963.

Hubbell S.P., Johnson L.K. (1978) Comparative foraging behaviour of six stingless bees exploiting a standardized resource, Ecology 59, 1123-1136.

Johnson L.K. (1987) Communication of food source location by the stingless bee Trigona fulviventris, in: Eder and Rembold (Ed.), Chemistry and Biology of Social Insects, Neotropical Bees. Ederc Rembold, Verlag, Peperny, Munchen.

Kajobe R., Echazarreta C.M. (2005) Temporal resource partitioning and climatological influences on colony flight and foraging of stingless bees (Apidae; Meliponini) in Ugandan tropical forests, Afr. J. Ecol. 43, 267-275

Kajobe R., Roubik D.W. (2006) Honey-making bee colony abundance and predation by apes and humans in a Uganda Forest Reserve, Biotropica 38, $1-9$.

Kleinert-Giovannini A., Imperatriz-Fonseca V.L. (1987) Aspects of the trophic niche of Melipona marginata marginata, Lepeletier (Apidae, Meliponinae), Apidologie 18, 69-100.

Milinski M., Parker G.A. (1991) Competition for resources, in: Krebs J.R., Davies N.B (Eds.), Behavioural Ecology - an Evolutionary approach, 3rd ed., Blackwell Scientific Publications, Oxford, UK, pp. 137-168.

Opler P.A. (1983) Nectar production in the tropical ecosystem, in: Bentley B., Elias T. (Eds.), The biology of nectarines, Columbia University Press, New York, pp. 30-79.

Ramalho M. (1990) Important bee plants for stingless bees (Melipona and Trigonini) and Africanized honey bees (Apis mellifera) in neotropical habitats: a review, Apidologie 21, 469-488.

Rohlf F.J., Sokal R.R. (1995) Statistical tables, 3rd ed., W.H. Freeman, San Francisco, CA.

Roubik D.W. (1989) Ecology and natural history of tropical bees, Cambridge University Press, New York.

Roubik D.W., Aluja M. (1983) Flight ranges of Melipona and Trigona in tropical forest (Hymenoptera: Apidae), J. Kans. Entomol. Soc. $56,217-222$.

Roubik D.W., Buchmann S.L. (1984) Nectar selection by Melipona and Apis mellifera (Hymenoptera: Apidae) and the ecology of nectar intake by bee colonies in a tropical forest, Oecologia 61, 1-10.

Roubik D.W., Moreno J.E., Vergara C., Wittmann D. (1986) Sporadic food competition with the African honey bee: projected impact on neotropical social bees, J. Trop. Ecol. 2, 97-111. 
Roubik D.W., Yanega D., Alluja S.M., Buchmann S.L., Inouye D.W. (1995) On optimal nectar foraging by some tropical bees (Hymenoptera: Apidae), Apidologie 26, 197-211.

Sawyer R.W. (1981) Pollen identification for beekeepers, UK University Collage, Cardiff Press, Cardiff, Wales.

Slaa E.J., Cevaal A., Sommeijer M.J. (1998) Floral constancy in Trigona stingless bees (Apidae, Meliponinae) foraging on artificial flower patches: a comparative study, J. Apic. Res. 37, 191-198.

Sommeijer M.J., De Rooy G.A., Punt W., de Bruijn L.L.M. (1983) A comparative study of foraging behaviour and pollen resources of various stingless bees (Hym., Meliponinae) and honeybees (Hym., Apidae) in Trinidad, West-Indies, Apidologie 14, 205-224.

Villanueva R.G (1994) Nectar sources of European and Africanized honey bees (Apis mellifera L.) in the Yucatan Peninsula, Mexico, J. Apic. Res. 33, 44 58.

Vit P., Medina M., Enriquez M.E. (2004) Quality standards for medicinal uses of Meliponinae honey in Guatemala, Mexico and Venezuela, Bee World 85, $2-5$. 